\title{
Fast breakthrough of resistant cytomegalovirus during secondary letermovir prophylaxis in a hematopoietic stem cell transplant recipient
}

\author{
Susanne Jung ${ }^{1}$, Manuela Michel ${ }^{2}$, Thomas Stamminger ${ }^{2}$ and Detlef Michel ${ }^{2^{*}}$ (D)
}

\begin{abstract}
Background: The compound letermovir (LMV) has recently been approved for the prophylaxis of cytomegalovirus (CMV) infection and disease in adult CMV seropositive recipients of an allogeneic hematopoietic stem cell transplant. LMV inhibits CMV replication by binding to the viral terminase complex. However, first cases of clinical LMV resistance have been occurred. Here we report a fast breakthrough of resistant cytomegalovirus during secondary LMV prophylaxis in a hematopoietic-cell transplant recipient.
\end{abstract}

Case presentation: A 44-year-old male patient with acute myeloid leukemia (AML) experienced a CMV-reactivation within the first 4 weeks of allogeneic hematopoietic-cell transplantation. Administration of LMV was initiated at day +34 . Due to increasing viral loads, LMV treatment was discontinued after 8 days. The patient was then administered with valganciclovir (valGCV) until viral DNA was undetectable. Due to neutropenia, valGCV treatment was switched to LMV secondary prophylaxis. For 4 weeks, the patient maintain virologic suppression. Then, CMV viral loads increased with a fast kinetic. Genotypic testing of the viral polymerase UL54, the kinase UL97 as well as the viral terminase UL56 and UL89 revealed the mutation C325Y in UL56, which is associated with the high level LMV resistance.

Conclusion: It is known that Letermovir is approved for prophylactic purposes. However, it may be used for some patients with CMV infection who either have failed prior therapies or are unable to tolerate other anti-CMV compounds. Particularly, the administration of LMV should be avoided in patients with detectable viral loads. When this is not possible, viral load must be routinely monitored along with UL56 genotyping. Furthermore, LMV administration at high virus loads may foster the rapid selection of resistant CMV mutants.

Keywords: Antiviral resistance, Cytomegalovirus, Letermovir, Genotyping, Allogenic hematopoietic-cell transplantation, Acute myeloid leukemia

\section{Background}

Cytomegalovirus (CMV) is still one of the reasons for causing severe complications after allogeneic hematopoietic-cell transplantation [1, 2]. Ganciclovir (GCV) and valganciclovir (valGCV) are routinely used for treating CMV infection in solid-organ transplantation. However, after hematopoietic-cell transplantation, GCV

\footnotetext{
* Correspondence: detlef.michel@uniklinik-ulm.de

${ }^{2}$ Institut für Virologie, Universitätsklinikum Ulm, Albert-Einstein-Allee 11, 89081 Ulm, Germany

Full list of author information is available at the end of the article
}

and valGCV are avoided due to the possibility of myelosuppression [3-5]. All traditional anti-CMV agents like $\mathrm{GCV}$, foscarnet, and cidofovir target the viral DNA polymerase [6]. In contrast, the compound letermovir (LMV) inhibits CMV replication by binding to components of the viral terminase complex and therefore offers a different mode of action [7-9]. In a recently published phase III study, CMV-seropositive transplant recipients received LMV at either a dose of $240 \mathrm{mg}$ per day for patients taking cyclosporine A or $480 \mathrm{mg}$ per day for patients without cyclosporine co-medication

(c) The Author(s). 2019 Open Access This article is distributed under the terms of the Creative Commons Attribution 4.0 International License (http://creativecommons.org/licenses/by/4.0/), which permits unrestricted use, distribution, and reproduction in any medium, provided you give appropriate credit to the original author(s) and the source, provide a link to the Creative Commons license, and indicate if changes were made. The Creative Commons Public Domain Dedication waiver (http://creativecommons.org/publicdomain/zero/1.0/) applies to the data made available in this article, unless otherwise stated. 
(https://www.accessdata.fda.gov/drugsatfda_docs/labe/2017/ 209939orig1s000,209940orig1s000lbl.pdf) [10]. The lack of cross-resistance with other anti-CMV compounds, the absence of myelosuppression as well as the positive results from the phase III study led to the recent approval of letermovir for the prophylaxis of CMV infection in CMV-seropositive adult hematopoietic-cell transplant recipients.

Genotypic resistance testing was performed directly from patient specimens. Therefore, fragments of $2100 \mathrm{bp}$ of the open reading frame (ORF) UL56 and $800 \mathrm{bp}$ of the ORF UL89 were amplified by polymerase chain reaction followed by Sanger sequencing. The sequencing analyses of UL56 and UL89 allow detection of all known mutations conferring LMV resistance. Genotyping of the viral polymerase UL54 and the UL97 kinase were performed as previously described [11].

\section{Case presentation}

The 44-year-old male acute myeloid leukemia (AML) patient received an unmanipulated graft from an unrelated donor (CMV D-/R+) after conditioning with the FLAMSA protocol. The patient received acyclovir (ACV, $400 \mathrm{mg}$ twice per day) continuously, except between days +43 to +70 and day +110 to +145 (summarized in Fig. 1). For maintenance of immunosuppression, the patient received cyclosporine A per os (measured blood concentrations 180-220 $\mu \mathrm{g} / \mathrm{L}$ ), mycophenolate (360 mg twice daily), and prednisolone.

It was planned to start LMV prophylaxis directly after the transplantation. However, due to a delay in delivery, administration of LMV could only be initiated at day + 34 , under the assumption that CMV viral load was still below detection limit $(50 \mathrm{IU} / \mathrm{ml}$ in serum). The compound was given at $240 \mathrm{mg}$ once per day per os, along with cyclosporine. In retrospect, it turned out that the virus DNA load at the last check on day + 28 was $190 \mathrm{IU} /$ $\mathrm{ml}$ in serum. Over the next 8 days, increasing CMV loads were measured up to $39.600 \mathrm{IU} / \mathrm{ml}$. Therefore, letermovir treatment was discontinued and the patient was switched to valganciclovir (valGCV, $900 \mathrm{mg}$ twice per day) at day + 42. Treatment was maintained for 4 weeks until CMV DNA was negative. At this time, the patient suffered from an intestinal graft-versus-host disease (GvHD) and a mucositis. Therefore, prednisolone was administered at day +46 for 7 days with $10 \mathrm{mg}$ and then was reduced to $1 \mathrm{mg}$ until discontinuation at day +82 .

As neutropenia occurred during valGCV therapy, stimulation with G-CSF was necessary. After discontinuation of valGCV, neutropenia was resolved and LMV secondary prophylaxis was started at day +70 with 240 mg once per day. At this time point CMV DNA was not detectable. At day +80 , mycophenolate was discontinued.
For 4 weeks, CMV DNA remained undetectable or at the limit of quantitation of $125 \mathrm{IU} / \mathrm{ml}$. At day +97 , tapering of cyclosporine A was initiated. However, several days later, the patient failed to maintain virologic suppression. CMV viral loads rapidly increased to $236.400 \mathrm{IU} / \mathrm{ml}$ in serum samples, between days +104 and +110 . In order to avoid neutropenia, valGCV treatment with a reduced dosage of $450 \mathrm{mg}$ twice per day was initiated at day +110 . Concomitantly, LMV dosage was increased to $480 \mathrm{mg}$ per day. During the next 4 weeks, CMV viral loads decreased to 1.200 $\mathrm{IU} / \mathrm{ml}$. ValGCV treatment, which meanwhile necessitated daily stimulation with G-CSF, was discontinued.

However, CMV DNA levels increased up to $33.000 \mathrm{IU} /$ $\mathrm{ml}$ during the following 2 weeks. Therefore, genotyping of the CMV terminase UL56 as well as the other relevant genes (UL97 kinase, viral polymerase UL54, and UL89) was initiated. Thereby, a mutation corresponding to amino acid 325 (C325Y, cytosine at amino acid 325 to tyrosine) of UL56 was detected (see Fig. 1). This mutation is associated with a high resistance to LMV in vitro [12]. Therefore, LMV was discontinued at day +167 .

No further mutation was detected. Retrospective analysis revealed that the UL56 mutation C325Y was already present at day +117 , within 6 weeks after the start of the second letermovir administration. Unfortunately, no other patient specimens were available in order to further elucidate the time point of emergence of the mutation.

Since then CMV DNA loads remained at a low level of 1300 to $2500 \mathrm{IU} / \mathrm{ml}$. Due to the lack of clinical symptoms and increasing CD4 T-cells since day +145 , no further anti-CMV therapy was carried out.

Until today, the patient is clinically stable and participates in a professional reintegration.

\section{Discussion and conclusions}

Recent clinical studies indicated that letermovir might be an important addition to the current strategies for prevention of active CMV infection and disease after allogeneic hematopoietic-cell transplantation and it may be useful for salvage therapies in solid organ recipients $[13,14]$. However, since the approval of the compound at the end of 2017, several patients have been reported who developed genotypically confirmed resistance to LMV while on therapy [15-18]. Thereby, LMV resistance emerged both in solid organ transplant and in hematopoietic stem cell transplant recipients. In nearly all cases which have been reported, LMV was used for salvage treatment, with considerable viral loads and for longer exposure times. In one case a breakthrough of CMV disease in a HSCT recipient occurred after more than 4 months of letermovir prophylaxis [18]. Contrary to the later, in the present case, we observed a rapid breakthrough of a resistant CMV upon secondary prophylaxis 


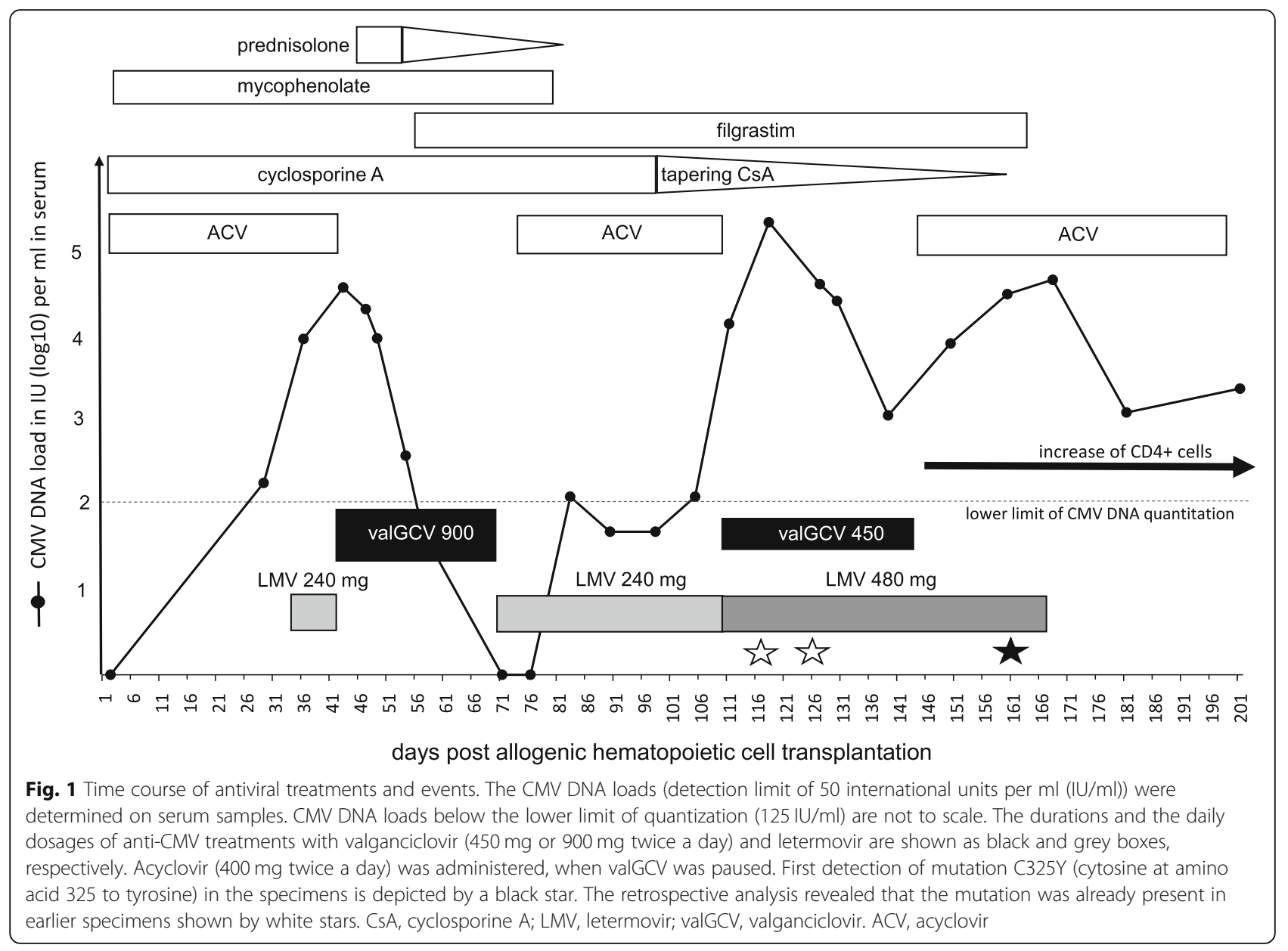

with LMV. Our patient has been re-challenged with the compound after a first short time exposure of 8 days. Thus, the question arose whether the selection of LMV-resistant viruses has already occurred during the first period of administration, because at that time virus loads were very high. On the other hand, re-administration of the drug resulted in successful suppression of virus replication for at least 30 days. Then, however, the resistant CMV subpopulation apparently prevailed. Unfortunately, due to the lack of appropriate patient specimens the question concerning the exact time point of emergence of LMV resistance cannot be answered unequivocally. Additional studies are needed to decide whether the re-exposure to letermovir during repeated periods of CMV reactivation poses a particular risk for the development of antiviral drug resistance.

Another question is, whether the dosage of LMV was too low for virus suppression at the time when cyclosporine was tapered. In a phase II prophylaxis trial, a single case of breakthrough CMV viremia on LMV prophylactic treatment had been published. Thereby, the UL56 mutation V236 M emerged on a daily dose of 60 mg suggesting that low-dose prophylaxis may confer letermovir resistance [19]. However, although cyclosporin is known to alter LMV pharmacokinetics, a dosage of $240 \mathrm{mg}$ letermovir even in the absence of CsA has been reported to be sufficient for complete suppression of viremia $[19,20]$.

We cannot exclude that individual reasons in this specific patient (e.g. compliance issues, nausea or atypical metabolism) led to low drug levels since no pharmacokinetic monitoring of LMV is available. Nonetheless, it is presently unclear whether higher doses of the drug would be more effective or safe during prolonged use since a recent study reported two patients who developed genotypically confirmed resistance to LMV while on therapy with $720 \mathrm{mg}$ and $960 \mathrm{mg}$ daily, respectively [16].

In vitro studies with serial viral passage in the presence of the compound have been associated with relatively rapid selection of several different UL56 mutations, particularly within codons 25 and 231 to 369 [21, 22]. Thereby, the different mutations led to diverse levels of resistance, ranging from a 5-fold increase in EC50 for V231L to > 5000-fold for C325Y [21, 22]. Remarkably, in 
all reports published after the approval of letermovir, the amino acid 325 in UL56 was exclusively affected [15-18]. In our case the mutation is also located at this codon. This suggests that amino acid 325 of UL56 may represent a hot spot for the occurrence of resistance upon clinical treatment. The presently available data suggest the necessity for fast genotyping for early detection of relevant mutations before treatment failure is evident.

According to the currently available data, letermovir should, if possible, only be used within the scope of the approval. Administration in patients at high risk with active CMV infections and considerable virus loads requires caution and close clinical and virological monitoring concerning the emergence of drug-resistant virus variants. Furthermore, LMV administration at high virus loads combined with (short time) drug exposures may foster the rapid selection of resistant CMV variants.

\section{Abbreviations}

allo-HCT: Hematopoietic-cell transplantation; AML: Acute myeloid leukemia; CMV: Human cytomegalovirus; LMV: Letermovir; PCR: Polymerase chain reaction; UL54: Unique long open reading frame 54; UL56: Unique long open reading frame 56; UL89: Unique long open reading frame 89; UL97: Unique long open reading frame 97

\section{Acknowledgements}

The consent of the patient for publication of this case is highly appreciated. DM thanks Dr. Peter Lischka and the reviewers for their constructive comments.

\section{Funding}

The authors have received no funding for the preparation of this manuscript. The authors declare that they have no conflicts of interests. The information has not been presented on any meeting.

\section{Availability of data and materials}

The datasets used and/or analyzed for the case study are available from the corresponding author on reasonable request.

\section{Authors' contributions}

All authors read and approved the final manuscript. SJ and DM have been involved in acquisition and interpretation of data. SJ has been involved in patient clinical care and reviewing medical records. MM and DM carried out the CMV genotyping and contributed to analysis. TS and DM drafted the manuscript. TS reviewed and revised this paper, and gave final approval to submit for publication.

\section{Ethics approval and consent to participate} Not applicable.

\section{Consent for publication}

Written informed consent was obtained from the patient for publication of this case. A copy of the written consent is available for review by the Editor-in-Chief of this journal.

\section{Competing interests}

D.M. was consultant for virological diagnosis for AiCuris GmbHCo.KG. The authors have received no funding for the preparation of this manuscript. The authors declare that they have no conflicts of interests.

\section{Publisher's Note}

Springer Nature remains neutral with regard to jurisdictional claims in published maps and institutional affiliations.

\section{Author details}

'Diakonissenkrankenhaus und Paulinenhilfe gGmbH, Diakonie-Klinikum Stuttgart, Rosenbergstraße 38, 70176 Stuttgart, Germany. ${ }^{2}$ Institut für Virologie, Universitätsklinikum Ulm, Albert-Einstein-Allee 11, 89081 Ulm, Germany.

Received: 8 August 2018 Accepted: 24 April 2019

Published online: 08 May 2019

\section{References}

1. Teira P, Battiwalla M, Ramanathan M, Barrett AJ, Ahn KW, Chen M, Green JS, Saad A, Antin JH, Savani BN, Lazarus HM, Seftel M, Saber W, Marks D, Aljurf M, Norkin M, Wingard JR, Lindemans CA, Boeckh M, Riches ML, Auletta JJ. Early cytomegalovirus reactivation remains associated with increased transplant-related mortality in the current era: a CIBMTR analysis. Blood. 2016;127:2427-38

2. Ljungman $\mathrm{P}$, Hakki M, Boeckh M. Cytomegalovirus in hematopoietic stem cell transplant recipients. Hematol Oncol Clin North Am. 2011;25:151-69.

3. Goodrich JM, Bowden RA, Fisher L, Keller C, Schoch G, Meyers JD. Ganciclovir prophylaxis to prevent cytomegalovirus disease after allogeneic marrow transplant. Ann Intern Med. 1993;118:173-8.

4. Humar A, Lebranchu Y, Vincenti F, Blumberg EA, Punch JD, Limaye AP, Abramowicz D, Jardine AG, Voulgari AT, Ives J, Hauser IA, Peeters P. The efficacy and safety of 200 days valganciclovir cytomegalovirus prophylaxis in high-risk kidney transplant recipients. Am J Transplant. 2010;10:1228-37.

5. Boeckh M, Ljungman P. How we treat cytomegalovirus in hematopoietic cell transplant recipients. Blood. 2009;113:5711-9.

6. Schreiber A, Harter G, Schubert A, Bunjes D, Mertens T, Michel D. Antiviral treatment of cytomegalovirus infection and resistant strains. Expert Opin Pharmacother. 2009;10:191-209.

7. Champier G, Couvreux A, Hantz S, Rametti A, Mazeron MC, Bouaziz S, Denis F, Alain S. Putative functional domains of human cytomegalovirus pUL56 involved in dimerization and benzimidazole D-ribonucleoside activity. Antivir Ther. 2008;13:643-54.

8. Lischka P, Hewlett G, Wunberg T, Baumeister J, Paulsen D, Goldner T, Ruebsamen-Schaeff $H$, Zimmermann $H$. In vitro and in vivo activities of the novel anticytomegalovirus compound AIC246. Antimicrob Agents Chemother. 2010;54:1290-7.

9. Goldner T, Hewlett G, Ettischer N, Ruebsamen-Schaeff H, Zimmermann H, Lischka P. The novel anticytomegalovirus compound AIC246 (Letermovir) inhibits human cytomegalovirus replication through a specific antiviral mechanism that involves the viral terminase. J Virol. 2011;85:10884-93.

10. Marty FM, Ljungman P, Chemaly RF, Maertens J, Dadwal SS, Duarte RF, Haider S, Ullmann AJ, Katayama Y, Brown J, Mullane KM, Boeckh M, Blumberg EA, Einsele H, Snydman DR, Kanda Y, DiNubile MJ, Teal VL, Wan H, Murata Y, Kartsonis NA, Leavitt RY, Badshah C. Letermovir prophylaxis for Cytomegalovirus in hematopoietic-cell transplantation. N Engl J Med. 2017;377:2433-44

11. Michel D, Höhn S, Haller T, Jun D, Mertens T. Aciclovir selects for ganciclovir-cross-resistance of human cytomegalovirus in vitro that is only in part explained by known mutations in the UL97 protein. J Med Virol. 2001;65(1):70-6.

12. Ligat G, Czal R, Hantz S, Alain S. The human cytomegalovirus terminase complex as an antiviral target: a close-up view. FEMS Microbiol Rev. 2018:42:137-45.

13. Lischka P, Zimmermann H. Antiviral strategies to combat cytomegalovirus infections in transplant recipients. Curr Opin Pharmacol. 2008:8:541-8.

14. Chemaly RF, Ullmann AJ, Stoelben S, Richard MP, Bornhäuser M, Groth C, Einsele $H$, Silverman M, Mullane KM, Brown J, Nowak H, Kölling K, Stobernack HP, Lischka P, Zimmermann H, Rübsamen-Schaeff H, Champlin RE, Ehninger G. AIC246 Study Team. Letermovir for cytomegalovirus prophylaxis in hematopoietic-cell transplantation. N Engl J Med. 2014;370:1781-9.

15. Frietsch JJ, Michel D, Stamminger T, Hunstig F, Birndt S, Schnetzke U, Scholl S, Hochhaus A, Hilgendorf I. In vivo emergence of UL56 C325Y Cytomegalovirus resistance to Letermovir in a patient with acute myeloid leukemia after hematopoietic cell transplantation. Mediterr J Hematol Infect Dis. 2019;11(1):e2019001. https://doi.org/10.4084/MJHID.2019.001 eCollection 2019.

16. Turner N, Strand A, Grewal DS, Cox G, Arif S, Baker AW, Maziarz EK, Saullo $\mathrm{JH}$, Wolfe CR. Use of Letermovir as Salvage Therapy for Drug-resistant CMV 
Retinitis: A Case Series. Antimicrob Agents Chemother. 2019. https://doi.org/ 10.1128/AAC.02337-18 [Epub ahead of print].

17. Knoll BM, Seiter K, Phillips A, Soave R. Breakthrough cytomegalovirus pneumonia in hematopoietic stem cell transplant recipient on letermovir prophylaxis. Bone Marrow Transplant. 2018. https://doi.org/10.1038/s41409018-0389-9. [Epub ahead of print].

18. Cherrier L, Nasar A, Goodlet KJ, Nailor MD, Tokman S, Chou S. Emergence of letermovir resistance in a lung transplant recipient with ganciclovir-resistant cytomegalovirus infection. Am J Transplant. 2018;18(12):3060-4. https://doi. org/10.1111/ajt.15135 Epub 2018 Oct 29.

19. Lischka P, Michel D, Zimmermann H. Characterization of Cytomegalovirus breakthrough events in a phase 2 prophylaxis trial of Letermovir (AIC246, MK 8228). J Infect Dis. 2016;213:23-30.

20. Kropeit D, von Richter O, Stobernack HP, Rübsamen-Schaeff $H$, Zimmermann H. Pharmacokinetics and safety of Letermovir Coadministered with cyclosporine a or tacrolimus in healthy subjects. Clin Pharm Drug Dev. 2017;7:9-21.

21. Goldner T, Hempel C, Ruebsamen-Schaeff H, Zimmermann H, Lischka P. Geno- and phenotypic characterization of human cytomegalovirus mutants selected in vitro after letermovir (AIC246) exposure. Antimicrob Agents Chemother. 2014;58:610-3.

22. Chou S. Approach to drug-resistant cytomegalovirus in transplant recipients. Curr Opin Infect Dis. 2015;28:293-9.

Ready to submit your research? Choose BMC and benefit from:

- fast, convenient online submission

- thorough peer review by experienced researchers in your field

- rapid publication on acceptance

- support for research data, including large and complex data types

- gold Open Access which fosters wider collaboration and increased citations

- maximum visibility for your research: over $100 \mathrm{M}$ website views per year

At $\mathrm{BMC}$, research is always in progress.

Learn more biomedcentral.com/submissions 